\title{
A Critical Examination of Heidegger's Thoughts: Technology Places Humanity in Shackles Hindering Our Natural Thinking Process and Our Connection to Being
}

\author{
Renee A. Pistone \\ Faculty, Writing Program, Rutgers University, New Brunswick, NJ USA \\ E-mail: rpistone@fas.harvard.edu
}

\begin{abstract}
Technological advancements such as artificial intelligence have encroached upon humanity's ability to think creatively. We rely on technical gadgets to add simple calculations and to retain listing and directories leading to memory loss. At times, we often cannot recall simple details and phone numbers since these things are all stored on our small hand-held computers. We must begin to consider how our technological advancements, in their many forms, are permeating our lives. As technology, especially computers, become increasingly smarter, we use our brains less resulting in a total surrender of our very lives to these gadgets. This marked and prolific worship of technology has separated us from our connection to our environment.
\end{abstract}

Keywords: Technology, Humanity, Science, Technological advancement

\section{Introduction}

Technology permeates every area of society essentially invading our lives. It can help ease our burdens, but there is a price to pay, as we lose the human touch. We just cannot seem to live without it and we crave new advancements. Now, is the time to start thinking about the impact that technology is having on our way of life. We can look at Martin Heidegger's philosophy to ascertain whether technology is truly helping us or whether its robbing of us our humanity (Dasein). A good reason to study the philosophy of technology is that its controversial. Heidegger develops a philosophy of technology that actually addresses the blending of science and technology. Heidegger seems to be writing in response to the rapid development of technology that he saw in his time.

\section{Problems Concerning Technology}

By investigating The Question Concerning Technology and Other Essays, The Essence of Human Freedom-An Introduction to Philosophy, Martin Heidegger: Basic Writings, a conclusion can be reached regarding the status of humanity in relation to the prolific role of technology in modern life. The essential question is to what extent does technology enslave the human race interfering with Dasein, our potential for the revelation of Being. Humans are increasingly being separated from nature because of technological advancement. We are forgetting how to think and to use properly use our brains since the machines do it all for us.

\subsection{Heidegger's Question Concerning Technology and Technoscience}

Heidegger's The Question Concerning Technology and Other Essays focuses on how technology obscures the essence of Being. The work begins by justifying his decision to investigate this issue. Clearly, technology helps us to better understand consciousness and Being. There will be changes to academic discourse as a result of the rise of technology. He is concerned about this and how human thinking may be altered. We can consider the relationship between Heidegger and metaphysics. Moreover, metaphysics define what things are and it tends to be historical. Meta-physics is a useful tool to define the state of technology (Thompson, 2000). Heidegger's thoughts on technology are most likely influenced by his extensive study on metaphysics (Heidegger, 1959). We know that Heidegger's first speech as Professor of Philosophy at Freiburg dealt with metaphysics (Moran\&Mooney, 2002). Using ideas that stem from his understanding of meta-physics, Heidegger puts forth the idea that meaning can be imputed to things and there are less absolutes in the philosophical realm. The Scholar Don Idhe's work entitled, "Was Heidegger Prescient Concerning Technoscience?" observes the following about what influenced Heidegger to write about technology:

The are strands which bear examination: First, the emergent philosophies of science at the beginning of the twentieth century which forefronted mathematization, in particular mathematical physics...second there was the powerful contemporary movement of Logical Positivism, and Logical Empiricism....and, third, there is Husserl! (Ihde, 2001). 


\subsection{Why technology?}

In short, the philosopher puts forth a method to inquire about the essence of technology. Truthfully, he presents the readers with ideas about how we live, versus the way in which, we should live. We are talking about thinking, as a process, and championing the human ability to think, over a technological machine's ability to process information. It is imperative that readers begin to think about Heidegger's motivations and interests in the philosophy of technology.

We shall be questioning concerning technology, and in so doing we should like to prepare a free relationship to it. The relationship will be free if it opens our human existence to the essence of technology. When we can respond to this essence, we shall be able to experience the technological within its own bounds (Heidegger, 1977).

Here, we begin to understand that he is talking about viewing technology as a force that is shaping the world. This impact our notion of experience as the art of technology structures experience. This principle can make one a bit nervous since issues of control and domination can stem from such a structure more easily. With the help of his ontological method, he can create a new way to relate to the issue of technology. He can depart from any traditional way of looking at the effects of modern technology and even from that particular discourse. It is important to consider that for Heidegger, Being was more likely to be ascertained through a series of thoughtful and deliberate questions concerning the specific topic that the scholar wanted to study. It seemed that the quest to know about Being was his main concern and all other topics surrounded this quest. It seems plausible that we are expected to consider: technology, freedom, and metaphysics, the subjects that Heidegger investigates, in relation to Being and the meaning of Being. Remarks from Taylor Carman's, Heidegger's Analytic: Interpretation, Discourse, and Authenticity in Being and Time, reflect how complicated Being is:

Heidegger does not assume that there is just one meaning. Indeed one of the central tenets of Being and Time is precisely that Being, in whichever grammatical form, means something fundamentally different for different

kinds of entities-existenz or being in the world (In-der-Welt-sein) for human beings, availability for things defined by their use, and occurrentness for objects, properties, and relations. The only unity Heidegger claims for the meaning of Being has to do with its general intelligibility in terms of some temporal framework, or horizon (Carmen, 2003).

\section{Applying a Theoretical Framework: The Issue of Technology}

Here, we see Being is not a topic, or even a word, that is easily defined or understood by most people. It is something that his readers will tend to struggle with. In this struggle, more information can be obtained about Being and the questions that we should be asking ourselves in relation to technology and Being. This quickly becomes an exploration because no one can say for sure what Being is, and what Being is not (Heidegger, 1962). We do know that it is our human dignity to ascertain a path towards the revelation of Being.

\subsection{Technology and Superficiality}

Rojcewicz (2006) chronicles the use of language to describe technology and its superficiality in the seminal work entitled, The Gods and Technology: A Reading of Heidegger. Clearly, Heidegger desires to carefully articulate his reasoning that technology is an obstacle to humans re-connecting with Being (Rojcewicz, 2006). Heidegger defines technology utilizing specific words as one scholar suggests, "Heidegger believes that we need to understand the correct or standard definition of technology before we can grasp the true definition of technology (Godzinski, 2005). The use of words, or etymological source for words, helps us clarify key definitions for words; therefore, our language serves to explain the meaning of technology, in relation to Being. Certainly, our language demonstrates the superficial nature of technology in our world. We can use language to help describe the complexity and to communicate meanings and definitions. Heidegger looks at the word techne and notes, "for the Greeks, techne meant a revelation of something, an uncovering or a bringing-forth (Heidegger, 1977). Catherine Frances Botha's, "Heidegger, Technology, and Ecology" explores the concept of techne as knowing (Botha, 2003). Therefore, Botha would likely agree that technology is an essence that is revealing.

\subsection{World: How We Experience Technology}

Heidegger does provide an explanation for what he means by world (Feenberg, 2005). Basically, world is not meant to denote every living thing, seen and unseen, as most people tend to think of it. Heidegger discusses the concept of world in terms of a "meaningful structure of experience" and this experience leads to a platform whereby Being can be known (Fennberg, 2005). Hence, when we question things, seeking truth and knowledge for its own sake, we move closer to Being. We move closer to the point whereby Being reveals itself to us. This is an important point for Heidegger who is chiefly concerned with thoughtful questions and not just simple questions in order to find an answer. For this reason, Heidegger teaches us how to think and to properly study a 
given topic. Heidegger describes Being as something beyond the most trivial descriptions, "in so far as Being constitutes what is asked about, and Being means the Being of entities, then entities themselves turn out to be what is interrogated (Heidegger, 1962). We begin to understand that these entities exist and have some special relation to Being. For Heidegger, Being can take the form of a series of questions, as we ascertain the meaning of Being. Technology relates to Being in that it reveals facts about our modern technological age. We can determine the meaning of entities, especially technological entities, by questioning which entities are useful to us.

\subsection{Implications for the Atomic Age}

In Discourse on Thinking: The Memorial Address featured in Part I describes some of the implications for the Atomic Age (Heidegger, 1966). Consider the answers that he gives regarding how this technology came about,

This is due to a revolution in leading concepts which has been going on for the past several centuries, and by which man is placed in a different world. This radical revolution in outlook has come about in modern philosophy. From this arises a completely new relation of man to the world and his place in it. The world now appears as an object open to the attacks of calculative thought, attacks that nothing is believed able any longer to resist. Nature becomes a gigantic gasoline station, an energy source for modern technology and industry. This relation of man to the world as such, in principle a technical one, developed in the seventeenth century first and only in Europe...the power concealed in modern technology determines the relation of man to that which exists. It rules the whole earth (Heidegger, 1966).

\section{Formulating a Theoretical Model for the Intersection between World and Technology}

Here, we see another example of the philosopher's view, as there seems to be a circumvention of humanity's chance to understand Being in the world. Technology is a mixed blessing, since we need it to fuel our lifestyle, but it often places an intolerable burden on Nature. Moreover, technology may lead us, not to ask the right questions, and to rush into conclusions, valuing the conclusions reached above the questions posed. This is a weakness, in any methodology, whether it be a scientific or a philosophical study. It is a form of technological thinking which has limited consequences and Heidegger calls this Enframing which leads to erosion of resources and the elaborate compilation of things imaginable in our consciousness (Heidegger, 1977). We have to continue to keep questioning and investigating because, as humans, we are Dasein, the actual facilitators for the self-revelation of Being in our world (Rojcewicz, 2006). For Heidegger, the essence of technology can distort truth and lessen our freedom to live as Dasein, as noted in the following:

the question concerning the essence of freedom is the fundamental problem of philosophy, even if the leading question thereof consists of Being (Heidegger, 2002).

We properly function as Dasein, when as we are seeking the revelation of Being. When we act as Dasein, we recognize and we seek the revelation of Being, in accordance with the perceptions from our body. Our body and senses, more specifically, allow for us to gain knowledge, and to understand what these perceptions mean. This is a rather complicated process as we take these actions in order to seek out the revelation of Being.

\section{Implications}

Interestingly, the idea that Nature, a precious thing, becomes a gas station is surely relevant today, due to our quest for greater consumption of energy. In fact, the possibility certainly does exist that the future consists of Nature versus technology. This notion or theory does not seem to be supported by Heidegger's ideas. We do know that the natural world suffers and our relationship to Nature is corrupt and exploitative. There used to be little to no reflection, at all, about what humans were doing to these natural environments and more importantly, how this strains our dignity to be Dasein. Hence, our natural thinking processes are eroding and our natural world is also degrading. This occurs largely, in part, because technology tends to facilitate technological thinking (that seeks to advance technology-artificial processes). It seems that the primary purpose of the advancement of technology is not to protect the environment. Also, pursuing an advancement in technology may not really lead to the revelation of Being since it helps machines gain greater control. We decide that we need more technology and moreinventions (that do complicated thinking, such as mathematical computations for us). Therefore, technology breeds more technology and our thirst for different varieties, in order to make our lives more convenient leads us to think less, about our lives in relation to Being. Heidegger articulates the following:

Only to the extent that man for his part is already Challenged to exploit the energies of nature can this revealing that orders happen...yet, precisely because man is challenged more originally than are the energies of nature, i.e., into the process of ordering, he never is transformed into mere standing-reserve. Since man drives technology forward, he takes part in ordering as a way of revealing (Heidegger, 1977).

Here, he explains to the readers about what drives humanity, as we attempt to order our world. He is not saying 
that we are in complete control over our world. It is not entirely clear whether or not technology gives us more or less control over this ordering process.

\section{Conclusion}

It is good to study Heidegger's idea about Being, dasein, and how technology fits into this situation. We are interested in technology because it impacts our daily lives as society is obsessed with it. Technology does encompass all of the human inventions in science. We can live better material lives because of the advancements that technology offers. There is the possibility that we will lose the ability to ask questions and investigate the mystery of Being. The prolific use of technology profoundly impacts our thinking processes. As a consequence, we tend to rely more on machines, rather than, on our own brains, to think. Heidegger provides the readers with a historical account of Being as it is meant to be thought of universal. Being is very hard to define as the question of all meanings never cease to be important to scholars. Interestingly, the many philosophical concepts, raised by Heidegger are difficult to define and to explain. Yet, technology is simply not as hard to explain. Moreover, reaching the conclusion that technology is impacting us in these expected ways, opens our eyes to the fact that, we do not have technology under control. Truly, we have dominion over the natural world, as we are, at the top of the food chain. It is disputed whether we have the same dominion over the mechanical, non-organic, technological world.

We saw that Heidegger was influenced by Nietzsche, and he does try to avoid the nihilism, that is, prevalent in his time. It does appear that many of the ideas that Heidegger presents, in these works, are advanced for his time period. The philosopher places his own understanding of Being at the core. He develops his notion of dasein from there with Being playing a role. In his matrix or paradigm, Being does not seem to be defined, as the absolute starting point for all things. It appears that dasein represents some type of form and function and related to the human drive for Being to be revealed. He uses a tactic called enframing to explain how all entities are grouped and utilized in society. This enframing process helps us to identify Being during our own lifetimes. It can be a pitfall, since technology cannot be overcome or overtaken by humanity but technology can, in fact, overpower us. In this manner, our relations with it are suspect because it holds power over us.

\section{References}

Being and Time. (1962). Trans. John Macquarrie and Edward Robinson, New York: Harper Collins Publishers.

Botha, Catherine. (2003). "Heidegger, Technology, and Ecology,” South African Journal of Philosophy 22 No. 2.

Carmen, Taylor. (2003). Heidegger's Analytic: Interpretation, Discourse, and Authority in Being and Time, New York: Cambridge University Press.

Discourse On Thinking Trans. (1966). John Anderson and Hans Freund, New York: Harper Press.

Feenberg, Andrew. (2005). Heidegger and Marcuse: The Capture and Redemption of History, New York: Routledge Press.

Godzinski, Ronald. (2005). "Framing Heidegger's Philosophy of Technology"Essays in Philosophy: A Biannual Journal 6, No. 1.

Heidegger, Martin. (1959). An Introduction to Metaphysics. Trans. Ralph Manheim,Connecticut: Yale University Press.

Ihde, Don. (2001). “Was Heideeger Prescient Concerning Technoscience?” Existentia Vol. 11.

Mooney, and Moran eds. (2002). The Phenomenology Reader, New York: Routledge Press.

Rojcewicz, Richard. (2006). The Gods and Technology: A Reading of Heidegger, Albany: State University of New York Press.

The Essence of Human Freedom: An Introduction to Philosophy, (2002). London: Continuum Press.

The Question Concerning Technology and Other Essays, (1977). New York: Harper Press.

Thompson, Iain. (2000). "What's Wrong with Being a Technological Essentialist? A Response to Feenberg," Inquiry Vol. 43. 